the success of inoculation against diphtheria, which has become available since he lectured to the Society in 1931. Systematic inoculation began in Hamilton, Ontario, in 1925, and the death-rate from diphtheria fell so steeply that after 1930 there were no more deaths and after 1933 no more cases. In Great Britain a full-scale preventive inoculation campaign was not inaugurated by the Ministry of Health until 1940 and was not fully under way until 1942. In 1940 there were still in England more than 45,000 cases of diphtheria, and more than 2,400 of these were fatal. As inoculation became effective, in spite of a counter-campaign, the numbers fell steeply and steadily until in 1954 there were only 173 cases; of the nine deaths, six were in children less than fifteen years old, and all in the minority who had not been inoculated. The value of preventive inoculation against tetanus is a more recent discovery, but there were only seven cases among the sixteen thousand wounded in the British Fxpeditionary Force in fighting its rearguard action to Dunkirk over soil known to be highly dangerous as a source of tetanus infection; these seven cases were all in the 10 per cent minority who had been persuaded to refuse protective inoculation.

Sir Henry also pointed out that the discovery of successful methods for immunizing dogs against distempor and the crippling condition known as 'hard pad' had, too, met a persistent campaign to induce owners to refuse this protection for their dogs. Sir Henry outlined some of the outstanding medical discoveries which had resulted from the experimental method during the past twenty-four years, such as mepacrine, the sulphonamides and penicillin, and the new types of anrsthetics; the use of some of these, such as curare, is still exposed to a cruel, if ineffective, campaign of denunciation and misrepresentation. The Research Defence Society, he said, needs and deserves all the support it can get in combating this attitude of blind obstruction.

\section{Linen Research Association: Report for 1955}

Tre report of the Council of the Linen Research Association for the year ended September 30, 1955 (pp. 20; from the Association, Lambeg, Belfast; 1955), refers to the support forthcoming from all sections of the industry - this in spite of the difficulties of the industry, which has not recovered from the setback of 1952. A special committee has been appointed to put before the Industrial Grants Committee of the Department of Scientific and Industrial Research a statement of the Association's policy and programme for the next five years and of its financial needs, and the Department has agreed to continue the present terms of grant for the first year of the new quinquennium, while raising the contribution needed to earn the maximum grant from $£ 32,000$ to $£ 40,000$ for the last four years of the quinquennium and the maximum grant itself from $£ 22,000$ to $£ 25,000$. The Association has experienced increasing difficulty in recruiting new staff, and in its spinning research has given priority to a new servo-drafting control mechanism, which should improvo the regularity of dry spun yarns and the dry spinning of flax to finer counts, and to a modified ring system for wet-spinning. A pneumatic tension gauge has been developed for measuring tensions on winding machines and dryspinning frames, and means have been devised for restricting the size of the yarn balloon when warping linen yarns at high speed. Attention has been given to improved methods of applying vat dyes to linen fabrics and to the application of resins and other polymers to linen fabrics.

In connexion with the difficulties of the linen industry, it may be noted that, replying in an adjournment debate in the House of Commons on January 31, the Parliamentary Secretary to the Board of Trade justified the Government's decision to close the flax processing mills operating in Great Britain. He said that, unless considerable sums are spent on plant and new machinery, many years of operation and research will be required to do more than touch the fringe of the problem, and the Government does not consider that continued expenditure of $£ 500,000$ a year from public funds to maintain a small scheme covering 16,000 acres of land is justified.

\section{Capper Pass Awards for Papers on Metallurgy}

The following Capper Pass Awards have been made by a joint committee representing the Institution of Mining and Metallurgy and the Institute of Metals for papers published during 1955 in the Transactions of the Institution and the Journal of the Institute: $£ 100$ to Dr. Maurice Cook, C. L. M. Cowley and E. R. Broadfield (use of refractories in low-frequency induction furnaces for melting copper alloys) ; $£ 100$ to P. M. J. Gray (extraction of uranium from a pyritic ore by acid pressure leaching); $£ 50$ to W. T. Edmunds and R. C. Lloyd (production of light-alloy drop forgings, their heat treatment, inspection and testing). The Awards are made from a fund given by Capper Pass and Son, Ltd., for the encouragement of scientific and technical papers dealing with processes and plant used in extraction metallurgy and on the subject of assaying, and also papers and processes used in all branches of the non-forrous metal industry.

\section{City and Guilds of London Institute : Fellowships}

The fellowship of the City and Guilds of London Institute has been conferred upon the following past students of the City and Guilds College or of Finsbury Technical College in recognition of their distinguished contributions to industry and the engineering profession: Dr. R. T. Colgate, chief technical works manager and chief chemist, Huntley and Palmers, Ltd., Reading; E. W. Moss, senior partner of Raworth, Moss and Cook, chartered patent agents; J. F. Pain, director of Dorman Long (Bridge and Engineering), Ltd. ; B. G. Robbins, secretary of the Institution of Mechanical Engineers; and Dr. F. H. Rolt, formerly superintendent of the Metrology Division of the National Physical Laboratory, Teddington.

\section{Psycho-Analysis and Contemporary Thought}

THE British Psycho-Analytical Society is arranging a series of six evening lectures commemorating the centenary of the birth of Sigmund Freud; they will be given in the Friends House, Euston Road, London, N.W.1, under the general title of "Psycho-Analysis and Contemporary Thought". The dates, lecturers and subjects are as follows: April 13, Marion Milner (psycho-analysis and art); April 17, Donald W. Winnicott (psycho-analysis and the sense of guilt); April 24, Dr. Roger Money-Kyrle (psycho-analysis and philosophy); April 27, Dr. Elliott Jaques (psycho-analysis and social problems in industry); May 1, Dr. John Bowlby (psycho-analysis and child care) ; May 8, Dr. Ilse Hellman (psycho-analysis and the teacher). Tickets (4s. each lecture or 1 guinea 